Eureka

France takes 'British' tack

President François Mitterand of France has travelled a long way since the heady days of his election in 1981, when he was prepared to see his government sink large sums of money into what now seem to have been ill-judged technological projects, particularly in the electronics industry. For despite putting FF1,000 million ( $£ 82$ million) of government money towards the 1986 budget of Eureka - the French-inspired project to get European industry behind a series of joint high-tech products - M. Mitterrand has put government support in second place to private funding, thus moving surprisingly close to the British position on Eureka.

This much emerges from a close reading of the text of his speech at the recent 17delegation European meeting on Eureka in Paris (see Nature 25 July, p.288), a text just released along with a speech of his research and technology minister, $\mathbf{M}$. Hubert Curien. M. Mitterrand said that "no-one would be surprised" if he claimed that "finance is one of the keys to the success" of Eureka. But, he said, the key was not only a question of the volume of finance, "but also of its origin".

In choosing Eureka projects, "We must create throughout Europe the opportunity for attractive investments", said Mitterrand. He made his appeal "to the market", adding almost as an afterthought, "but also to the support of governments". Only then did he offer his FF1,000 million, quite a paltry sum by the scale of the enterprises envisaged, and by comparison to the $\$ 26$ million proposed in the United States for the first five years of the Strategic Defense Initiative, which first crystallized French thinking on Eureka.

By contrast, M. Curien adopted a slightly more "from the top down" approach, speaking of the need "to propose certain concrete technological challenges to our industrialists". For Curien "there must be no delay, the international context makes action imperative", but he felt that already there was sufficient support behind "a certain number" of French proposals (for a list see Nature 11 July, p.97) for it to be "scarcely in doubt" that Eureka would soon be moving.

Curien saw the criteria for selecting projects for Eureka to be:

- That they should lead to the development of high technologies having economic or "strategic" importance.

- That they should lead to a product of "original performance" which could find a place on the market.

- That they should involve many partners - private or public - " which should provide a substantial part of the finance".

- And that they should unite many European countries.

In relation to the European Commission, these projects should be considered as forerunners of Commission efforts to create afresh a real common market for products, and complementary to the Commission's precompetitive research exercises ESPRIT (information technology), BRITE (technology for old industries) and RACE (telecommunications), Curien said. Eureka completed and amplified the decision of the Council of Europe last September, also prompted by France, to create a variety of networks of European researchers (Nature 311, 197; 1984) where "much has already been done but much remains to do". Eureka is an "indispensable complement" to such "more general" research actions.

As for government finance, said $\mathrm{Cu}$ rien, "It is scarcely in doubt that we must draw on the public purse in proportion to the degree of technological risk of each project". But France already devotes "a substantial part" of its research and development budget to the technologies covered by Eureka. And hence "we are waiting for a parallel response from industry", he said.

Robert Walgate

\section{Balancing the books}

Perhaps one reason why the French President $M$. François Mitterrand is being a little cautious about committing huge sums of government money to his pet project Eureka (see above) is that the cupboard is bare. For now is the time that the French cabinet prepares the budget for 1986 election year - and it seems the purse strings are about to be drawn very tight.

In current francs the government budget is expected to exceed the figure of 1 million million ( $\$ 82,000$ million) for the first time; but in real terms, this amounts to zero growth. Nevertheless, there will be growth in some areas and among the lucky ministers is likely to be the minister of research. The present incumbent, $M$. Hubert Curien, might expect to receive the modest budget increase of 4 per cent in real terms for which he asked. Education is also likely to be protected, but aid to industry, agriculture and other sectors may fall 4 per cent, and defence 2 per cent.

Curien's 4 per cent increase should be compared to nearly 6 per cent last year, and would put around another FF 1,500 million on the French civil research and development budget. President Mitterrand has offered FF 1,000 million to Eureka. But whether this sum would come from Curien's increase, from a redistribution of existing sums, or as extra real money is not yet clear. Final details of the budget will not be decided until a cabinet meeting in September; it will then go to parliament in mid-October.

Robert Walgate
SDI

\section{Physicists jib at inducements \\ Washington}

AN attempt at a boycott is being organized by several hundred academics opposed to President Reagan's Strategic Defense Initiative (SDI). They have signed a statement pledging themselves not to apply for or accept support from the SDI organization. A statement circulated by John Kogut, a theoretical physicist from the University of Illinois, condemns SDI (commonly known as star wars) as "technically dubious and politically unwise", saying it is "a step towards the type of weapons and strategy most likely to trigger a nuclear holocaust". A similar statement has been circulated by David Wright of Cornell University, and work is in progress on a joint version to be circulated to science departments all over the United States.

Kogut says he drafted his statement in response to "partisan" claims for SDI made in a brochure sent out from the SDI organization's Innovative Science and Technology Office. The brochure, which reads more like the work of a Madison Avenue advertising agency than a military department, speaks in ecstatic terms of "new and exciting" times for scientists who participate in "fascinating and challenging" SDI research.

Kogut objects to the implication that universities are "falling over themselves" to get star wars funds, and has persuaded 52 of the 72 members of his physics department to sign his protest. Physicists from

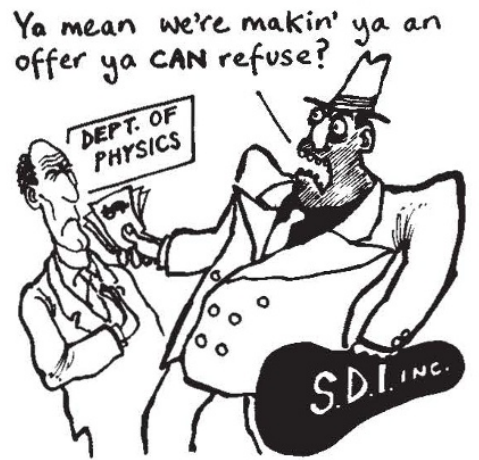

the Institute of Theoretical Physics at Santa Barbara, from Fermilab and from the IBM Watson research laboratories at Yorktown have also signed and, according to Kogut, the number "is growing all the time". A similar petition organized earlier this year by the Union of Concerned Scientists attracted the signatures of 700 members of the National Academy of Sciences, including 54 Nobel laureates.

Kogut admits that many of those who signed his declaration are motivated by political considerations, but says that some also thought that the brochure specified unrealistic goals. The University of Illinois is a designated supercomputer 